\title{
Mengkritisi Asas-asas Hukum Acara Perdata
}

\author{
Busyro Muqaddas
}

\begin{abstract}
The critical thinking on civil law procedure must be put on the frame and spectrum of comprehensive thnking, namely how is the role of judicative body on the more basic agenda, namely to give the contribution for civil conflict solution, to recover and distribute right and responsibility proporsionally. It also recovers the public balance, give law protection for individual through considering public right and interest.
\end{abstract}

\section{Pendahuluan}

Kualitas keberadaan pengadilan selama ini menunjukkan semakin mengalami distorsi dari peran utamanya yaitu sebagai the last struggle bagi justisiabelen pada khususnya dan harapan masyarakat pada umumnya. Peran dan misi pengadilan yang seharusnya independen secara penuh dalam keberpihakan kepada kesetiaan atas nilai-nilai keadilan kebenaran, telah banyak mengalami proses pembusukan yang cukup signifikan. Kondisi ini telah lama dialami sejak rezim orde lama dan dilanjutkan dalam masa orde baru yang, efek destruktifnya masih terasa hingga sekarang ini. Dalam dua era rezim itu, pengadilan sebagai wujud dari kekuasaan kehakiman -dan kekuasaan kehakiman sebagai wujud dari RI sebagai rechtsstaat telah menunjukkan perannya bukan sebagai badan peradilan yang independen, melainkan justru sebagai alat kekuasaan yang otoriter. ${ }^{1}$

Mengingat latar sejarah pengadilan yang berjalan dalam kurun waktu yang cukup lama itu, wajar jika kini masih dapat dirasakan terdapatnya sikap masyarakat yang sinis, apatis bahkan hopeless terhadap keberadaan dan peran pengadilan. Sikap yang tidak menguntungkan terhadap citra pengadilan ini, akan mengalami eskalasi dan perluasan pengaruhnya disaat seperti sekarang ini, dengan alasan: Pertama, masyarakat telah

'Penilaian yang sama dikemukan pula oleh Daniel Lev: "Tidak dapat disangkal bahwa sistem peradilan di Indonesia rusak sesudah empat puluh tahun Demokrasi Terpimpin dan Orde Baru." Daniel S. Lev. 2001. Advokat Indonesia Mencari Legitimasi. Jakarta, PSHK dan The Asia Foundation. HIm. viii. 
mengalami proses akumulasi kekecewaan yang telah berjalan begitu lama. Dapat dibayangkan ratusan kasus baik pidana umum, pidana khusus seperti korupsi, politik, maupun perdata, serta sejumlah kasus struktural yang selama itu lebih banyak menghasilkan vonis hakim yang berpihak kepada penguasa, dan kepada pihak yang kuat loby finansiilnya, semuanya ini telah merupakan andil buruk bagi terbentuknya penggumpalan kekecewaan massif yang sudah merupakan gunung es dan bersifat eksplosif itu. Kedua, semakin menguatnya pengetahuan dan kesadaran masyarakat tentang terjadinya praktik kolusi dan manipulasi di pengadilan yang secara umum telah memberi andil bagi dirampasnya hak-hak publik untuk memperoleh keadilan dan kebenaran lewat putusan hakim. Ketiga, munculnya kecenderungan yang menarik dimasyarakat dengan terbentuknya. sejumlah organisasi yang bersifat non governmental (NGO)di berbagai daerah. Organisasi yang memiliki visi dan komitmen untuk melancarkan gerakan social control terhadap berjalannya institusi-institusi publik seperti pengadilan telah berperan positif dalam memberikan mediasi dan advokasi bagi hak-hak publik yang diabaikan oleh pejabat publik seperti hakim.

Keberadaan dan pola kerja/pola juang mereka tidak layak untuk diabaikan siapapun, karena telah merupakan meanstream dengan karakternya yang independen dan. non partisan. Jaringan kerja (networks) yang bersifat tali temali diantara mereka, patut dikalkulasi sebagai kekuatan moral yang berpengaruh terhadap proses-proses politik di mana hakhak dan kepentingan publik sering kali diabaikan begitu saja dalam sistem kekuasaan yang otoriter dan anti demokrasi serta eksklusif. ${ }^{2}$

Dengan dukungan pers yang independen dan kritis yang mengkomunikasikan gerakan advokasi struktural oleh katangan NGO kepada publik, telah berhasil menyadarkan publik akan arti penting suatu sikap berani membela dan memperjuangkan kepentingan sendiri (self protection ) dalam bentuk pembelaan yang bersifat swadaya. Kesadaran massif ini positif bagi kepentingan penguatan publik, dan sebaliknya dapat dianggap sebagai ancaman bagi penguasa yang masih mengidap sisasisa mentalitas kekuasaan otoriter dan status quo.

Jika melalui jaringan NGO dan dukungan pers publik dapat menemukan arti penting sebuah gerakan perlawanan melalui jalur hukum, namun pada sisi lain, dilihat dari urgensi pendidikan hukum bagi masyarakat, kondisi-pengadilan yang masih jauh dari peran idealnya itu, akan berdampak buruk pada potensi munculnya tindakan sebagian masyarakat di luar jalur hukum dalam menyikapi situasi atau kejadian yang muncul disekitarnya. Merebaknya tindakan street justice dalam bentuk pembakaran hidup-hidup pelaku kriminal oleh kelompok masyarakat

${ }^{2}$ Tentang pola kerja sejumlah NGO yang berorientasi pada social empowerment movementini, secara khusus memiliki peran yang signifikan dalam kaitan dengan upaya menuju pembentukan másyarakat sipil. Dalam konsep Mansour Fakih, masyarakat sipil dirumuskan sebagai masyarakat yang terdiri dari berbagai bentuk organisasi voluntir yang merupakan dunia politik utama, yang berada dalam sebuah aktivitas ideologis dan intelektual dinamis. Mansour Fakih. 1996. Masyarakat Sipil. Yogyakarta: Pustaka Pelajar. HIm. 59. 
dengan suka ria disejumlah daerah membuktikan dampak buruk itu yang telah mengindikasikan rapuhnya kepercayaan dan harapan publik kepada pengadilan, di samping terhadap aparat kepolisian. Tindakan main hakim sendiri kendatipun merupakan bentuk tindakan kriminal juga, namun ini tidak dapat dilepaskan dari proses pembusukan di dalam lembaga pengadilan Indonesia.

- Ditinjau dari perspektif "masyarakat tamaddun/masyarakat madany" yang menurut Anwar lbrahim menuntut dipenuhinya prinsip moral, keadilan, keseksamaan, musyawarah dan demokrasi, maka aparat pengadilan seharusnya secara institusional menyikapi proses pembusukan diberbagai lini kehidupan kenegaraan dewasa ini sebagai strategic momentum untuk mewujudkan prinsip-prinsip masyarakat tamaddun di atas dalam prosesproses peradilan.

Sesuai dengan spirit yang tercantum dalam Pasal 1 UU No.14 Tahun 1970 tentang Pokok-Pokok Kekuasaan Kehakiman yang memberikan kebebasan bagi hakim untuk secara independen melakukan tugas dan perannya sebagai penegak kebenaran dan keadilan, maka strategic momentum ini dapat diletakkan dalam suatu kerangka inovasi secara jelas dan komprehensif dan fundamental. Mengingat bahwa akar permasalahan dasarnya yang menjadikan wajah pengadilan tercemar adalah berawal dari ketidak jelasan landasan konsep filosofis mengenai makna keberadaan, peran, dan misi pengadilan, maka upaya mengkritisi asas-asas hukum acara perdata perlu diletakkan dalam kerangka menyeluruh bagi perbaikan seluruh sistem peradilan.
Ditinjau dari pendekatan sistem, badan peradilan khusus maupun umum terikat dengan asas-asas umum yang bersifat fundamental sebagaimana diatur dalam UU No. 14 Tahun 1970. Asas-asas Hukum Acara Perdata juga memiliki sumber dari sini. Di samping itu, hendaknya perlu difahami bahwa, keberadaan badan-badan peradilan di indonesia tidak dapat dilepaskan kaitan perannya untuk mewujudkan kebenaran dan keadilan dalam bingkai konsep Rechtsidee (cita hukum). Dalam pandangan Moeh Koesnoe, rechtsidee ini terdapat dalam rumusan Pembukaan UUD 1945. Keberadaan badanbadan peradilan dalam pola masyarakat dan negara Indonesia menuju pada tatanan dan kualitas kehidupan menuju masyarakat madani.

Persoalannya adalah bahwa, sejauh mana diperlukan suatu persepsi dan tafsir akademik yang tepat terhadap substansi rumusan Rechtsidee, yang secara akademik dapat menjadi salah satu rujukan bagi kalangan hakim. Dalam pada itu pula, bertitik tolak dari tafsir atas Rechtsidee itu kemudian dapat dielaborasi pengertian-pengertian substansiilnya yang memiliki kaitan relasional dan kontekstualnya dengan agenda menuju masyarakat madani. Dengan kerangka demikian, pemikiran yang bersifat mengkritisi Asas-asas Hukum Acara Perdata, diletakkan dalam tiga perspektif: Pertama, perspektif filosofis yang berlandas pacu pada rechts idee yang terdapat dalam Pembukaan UUD 1945. Kedua, perspektif sosiologis yang berusaha merespon agenda kolektif menuju masyarakat madani, dan ketiga, perspektif normatif yang bertitik tolak dari spirit yang terkandung dalam Pasal 1 UU No. 14 Tahun 1970. 


\section{Telaah perspektif filosofis.}

Upaya pemikiran eksploratif dan inovatif dalam rangka untuk menemukan elemenelemen esensial mengenai hukum acara perdata sebagai bidang hukum prosedural memiliki arti yang signifikan. Di antara alasan yang dapat dikemukakan untuk memberikan ilustrasi pentingnya upaya itu adalah masih kuatnya pandangan dikalangan hakim yang mencerminkan paradigma 'positivistik. Semangat pandang formalisme pada bunyi tesktual suatu peraturan perundangan maupun doktrin/postulat-postulat hukum tertentu masih amat menonjol, tanpa bisa ditemukan suatu kecenderungan umum pada pemikiran hakim itu yang bersifat apresiatif terhadap tafsir-tafsir kritis yang dapat menolong penemuan nilainilai fundamental yang bersifat intrinsik di balik teks peraturan perundangan maupun doktrindoktrin hukum

Dalam kurun waktu dua puluh tiga tahun sebagai lawyer yang berinteraksi dengan para hakim dan para jaksa serta counter part sesama lawyer, dapat ditarik benang merah tentang bagaimana proses pengadilan sebagai suatu proses pengidentifikasian, pemecahan dan penemuan hukum atas suatu kasus perdata maupun kasus hukum lainnya, lebih sering mencerminkan suatu proses yang bersifat tehnis mekanistik, yang mirip dengan cara kerja suatu mesin. Dalam proses persidangan dengan kecenderungan sepertj ini, sulit ditemukan iklim persidangan dimana para pihak dan hakim tampak merefleksikan pemikiran dan sikap elegan yang kontemplatif, rasional, radikal, sistematis dan kritis sebagai ciri berpikir filosofis - yang diperlukan dalam mengadili suatu sengketa perkara.

Hukum acara perdata sebagai himpunan kaedah beracara, secara substansial mengandung makna, bagaimana para pihak, terutama hakim sebagai pemimpin sidang, memiliki kapasitas intelektual, spiritual dan integritas profesi untuk melakukan tahapan sidang yang terdiri dari legal problem identification, legal problem solving dan decision making atas suatu sengketa. Melalui tiga tahap ini, hakim memiliki tugas mengadili menurut hukum.(Pasal 5 ayat 1) UU No. 14 Tahun 1970, dengan kewajiban menggali, mengikuti dan memahami nilai-nilai hukum yang hidup dalam masyarakat (Pasal 27 ayat 1) undangundang yang sama. Menggali nilai-nilai hukum yang hidup dalam suatu masyarakat tentu memerlukan pendekatan filsafati.

Permasalahan yang acap kali muncul di dalam praktik persidangan, terletak pàda sementara hakim yang memiliki keterbatasan pada ketiga kapasitas di atas. Faktor ini akan berpengaruh pada kemampuannya untuk melakukan pemaknaan atas fakta sosial yang selanjutnya akan dikonversi menjadi fakta hukum. Pada tingkat ini saja, jika terdapat kesalahan pemaknaan secara substansial, akan berpengaruh pada kualitas putusannya.

Dalam mekanisme persidangan, hakim akan dihadapkan pada sejumlah fakta sosial, baik yang diajukan oleh para pihak yang bersengketa, maupun, - jika hakim aktif - ia temukan melalui kecermatannya dalam memimpin persidangan. Pada tahap ketika hakim sampai pada tingkat mengkonversi fakta sosial menjadi fakta hukum, ia sudah mulai berada pada tahap bersentuhan dengan pendektan filsafati, tidak lagi hanya tehnis mekanistik. Jika ia cermat dalam memaknai -melalui penafsiran - atas sejumlah fakta sosial dan kemudian ia memiliki kemampuan menganalisisnya dari perspektif filsafati, maka hasil yang akan diperoleh adalah fakta hukum 
yang merupakan out put dari pergumulan (analisis kritis) dan simbiosis kualitatif yang berbobot etis yuridis.

Sebagai salah satu contoh yang merepresentasikan sebuah pergumulan pemikiran hukum yang mencerminkan perasan keadilan (sense of justice) dalam suatu putusan perkara perdata, dapat menyontoh pada gugatan tuntutan ganti rugi tanah yang diajukan oleh petani' miskin di kawasan Kedongombo yang pada pengadilan tingkat pertama dan tingkat banding, tuntutan ganti rugi $\mathrm{Rp}$ 10.000/m2 ditolak, tetapi pada tingkat kasasi justeru dikabulkan dengan jumlah yang melebihi daripada yang dituntut para petani itu yaitu $\mathrm{Rp} 50.000 / \mathrm{m} 2$.

Putusan hakim pada kedua tingkatan itu yang berbeda dengan tingkat kasasi ini, secara jelas menggambarkan bagaimana suatu konstruksi konsep hukum dari para hakim yang mengadili satu kasus menghasilkan perbedaan putusan yang sangat substansial. Pada kedua putusan sebelum kasasi tergambarkan bagaimana paradigma positivisme telah berhasil mengkerangkai cara berikir hakim dengan putusannya yang menolak tuntutan ganti rugi itu, sedang pada tingkat kasasi yang terlihat secara antagonistik adalah suatu paradigma hukum yang mencerminkan kandungan pemikiran hukum yang merefleksikan visi-sosial yang kental. Putusan majelis hakim tingkat kasasi yang mengabulkan tuntutan ganti rugi sebesar Rp $50.000 / \mathrm{m} 2$ yang justru melebihi dari pada yang dituntut para petani gurem sebagai pihak yang memperjuangkan keadilan sosial di depan hidung penguasa Orde Baru yang otoriter ketika itu, menunjukkan suatu parameter kebenaran dan asas hukum yang berkeadilan sosial yang terkandung di dalam putusannya. ${ }^{3}$ Kasus ini memberikan contoh menarik di mana majelis hakim yang diketuai Prof Asikin Kusuma Atmaja telah melakukan tafsir (pendekatan hermeneutik) kontekstual yang

${ }^{3}$ Tentang putusan tingkat kasasi ini, Purwoto, ketua Mahkamah Agung waktu itu menilainya sebagai bertentangan dengan hukum, dengan alasan karena melebihi daripada yang diminta para penggugat sebagaimana dikutip Kompas. 17 Oktober 1994. Catatan Penulis: Memang terdapat suatu sistem aturan, dimana pada prinsipnya hakim terikat dengan undang-undang dalam memeriksa dan mengadili suatu sengketa (Pasal 20 Algemene Bepaling van Wetgeving). Namun berdasarkan Pasal 5 (ayat 1) dan Pasal 27 (ayat 1) UU.No.14 Tahun 1970, hakim memiliki landas pijak yuridis untuk tidak sepenuhnya terikat pada undangundang. Bahkan bilamana dengan mendasarkan pada undang-undang secara ketat justru melahirkan putusan yang tidak benar dan tidak adil, maka secara independen, dengan kapasitas intelektualitas, spiritualitas dan integritas profesi yang melekat pada hakim, apa yang merupakan isi suatu undang-undang dapat diabaikan penerapannya. Jadi, undang-undangnya tetap ada, namun konteks sosial dimana putusan hakim akan diterapkan dimạsyarakat tidak memungkinkan hakim menerapkannya. Lebih jauh bandingkan dengan model peradilan Islam yang pernah diterapkan oleh Khalifah 'Umar Ibn Khatab yang dalam suatu putusannya tidak menerapkan hukum potong tangan yang begitu jelas nashnya dalam kitab suci Al-Qur'an Surat Al Maidah ayat 38 yang menyatakan bahwa pencuri laki-laki maupun perempuan diancam dengan pidana potong tangan. Alasan Khalifah 'Umar adalah karena pencurian terjadi pada situasi yang secara umum sedang paceklik. Pencurian dinilainya sebagai unsur keterpaksaan. Ahmad Azhar Basyir. 1993. MA: Refleksi atas Persoalan Keislaman. Bandung: Mizan. HIm. 125. 
secara tajam dan radikal memantulkan sensitifitas keadilan sosial. ${ }^{4}$ Dari putusan ini pula diperoleh contoh putusan hakim yang jenis langka, yang dida lamnya memuat kandungan aspek intelektualitas, spiritualitas dan integritas profesi Sang Hakim Agung.

Di dalam hukum dikandung suatu asas. Asas hukum sebagai suatu nilai-nilai fundamental yang bersifat instrinsik selalu memerlukan pendekatan hermeneutik, ${ }^{5}$ guna memperoleh pengertian-pengertiannya yang substansiil, aktual dan memiliki makna relasional, yaitu, suatu makna yang dapat dilacak/digeledah dari suatu teks undangundang atau doktrin yang mengait dengan realitas atau problematik sosio kultural yang pada situasi tertentu, dipandang perlu bagi upaya menemukan makna yarig sejatinya (hakiki) dari berbagai sisi suatu undangundang atau doktrin. Disinilah letak permasalahan yang cukup mengakar dan fundamental ketika suatu asas hukum dihadapkan pada keperluan untuk ditelaah secara kritis. Agar dengan demikian -kata maupun kalimat dalam suatu teks undangundang yang bersifat pasif tidak dibiarkan sedemikian rupa tanpa makna, yang akan berakibat pada kesalahan substansial, terutama jika hal ini dilakukan oleh kalangan hakim secara luas.
Faedah pendekatan ini adalah untuk memperoleh makna substansialnya yang terdalam, makna kontekstualnya dan tujuantujuan yang dimaksud oleh perumusnya ketika asas hukum baik yang terdapat dalam suatu undang-undang maupun doktrin disusun. Juga agar dapat memperoleh relefansi maknawinya dengan situasi sekarang ketika. suatu udangundang atupun doktrin akan diterapkan dalam suatu kasus baru dengan konteks sosio kultural baru, bahkan mungkin berbeda dengan masa lalu ketika hal itu disusun. Faktor lain yang perlu dipertimbangkan dalam penerapan suatu asas hukum adalah berkaitan dengan perlindungan kepentingan publik, agar out put yang diperoleh menghasilkan keseimbangan , antara perlindungan kepentingan individual dengan kepentingan publik. Keseimbangan dalam arti proporsionalitas ini diperlukan dalam masyarakat yang tidak menganut falsafah individualisme

Permasalahan berikut yaing secara spesifik adalah; berkaitan aktivitas hakim dalam menemukan dan menerapkan suatu asas hukum dalam proses pengadilan perdata. Permasalahan ini muncul terkait dengan adanya meanstream pemikiran klasik dikalangan para hakim bahkan juga dalam pendidikan hukum bahwa, hukum perdata adalah masuk dalam wilayah hukum privat

${ }^{4}$ Tentang konsep Keadilan Sosial, antara lain dapat dirujuk pada pendapat lbnu Taimiyah yaitu suatu konsep keadilan dalam as -Siyasyah asy-Syar'iyah yang bertujuan untuk melayani kepentingan publik yang berfungsi menjembatani jurang pemisah antara kepentingan penguasa dengan rakyatnya (ar -Ra'iwa arRa'iyah) dengan tujuan akhir memajukan kondisi-kondisi sosial. Majid Khadduri. 1999. Teologi Keadilan;perspektif Islam. Risalah Gusti. HIm. 265: Istilah Keadilan Sosial memperoleh tempat sebagai sila ke lima Pancasila yang secara realistik masih merupakan jargon politik dan abstrak dan tidak pernah membumi serta jarang dijadikan sumber inspirasi bagi kalangan hakim dalam proses pembentukan hukum dalam bentuk putusan hakim/vonis yang berpihak pada nilaikebenaran dan keadilan. 
yang melibatkan konflik antara individu. Pemahaman yang terbatas sampai pada pengertian yang simplistis ini, acap kali menimbulkan penilaian .hakim ıyang. kurang proporsional dimana, suatu sengketa perkara perdata dipandang dari perspẹktif hubungan keperdataan yang tidak memiliki. relevansi sosio kultural sama sekali. Tentu saja penilaian semacam ini kurang 'memiliki pijakan akademis: di antara argumennya adalàh, karena suatu undang-undang disusun dan diterapkan tidak lepas sama- sekali- dari faktor agama, moral, sosial, ékonomi; politik dan kultural - masyarakatnya.. Sejumlah putusan hakim mengenai kasus tertentu menggambarkan adanya -kerangka berfikir yang menganggap bahwa sengketa perdata adalah sengketa antar individu yang tidak memiliki keterkaitan dengan faktor-faktor sosio kultural politik.

Salah satu contoh yang secara: jelas mengkonstruksikan paradigma hukum yang tidak begitu mencerminkan nilai-nilai asasi dalam penerapan asas hukum acara perdata adalah, dapat-dilihat pada penerapan "asas kebenaran formil"' (kebenaran yang sematamata ditunjukkan dalam bukti-bukti formil dimuka sidang sesuai teori "preponderance of evidence"), khususnya untuk kasus-kasus struktural, seperti. pada putusan tingkat pertama dan tingkat banding pada kasus Kedongombo. Di sini tampak bagaimana hakim berkutat secara normatif pada apa yang secara formil-diajukan tuntutan oleh warga Kedongombo. Dasar pikiran. hakim adalah Pasal. 178 HIR ayat (3) (P.asal 189 ayat (3) Rbg dan Pasal 50 ayat (3) Rv) yang intinya, hakim dilarang menjatuhkan putusan atas perkara yang tidak dituntut atau meluluskan lebih dari pada yang dituntut. Demikian juga, penilaian Purwoto terhadap putusan tingkat kasasi dalam kasus ini yang isinya "menerjang" ketentuan pasal-pasal warisan kolonial Bielanda itu. Keduanya itu menggambarkan keringnya ketajaman intelektualitas dan rendahnya kepekaan spiritualitas hakim.

$\therefore$ Penggambaran mengenai penerapan asas kebenaran formil yang masih dominan dalam berbagai , putusan hakim, dapat menjadi dasar pembenar dalam arti norm judg; ment, bukan moral judgment, dalam situasi dimana pengadilan berada dalam pengaruh - dan menjadi sebuah instrumen - dari kekuasaan yang dominan, ${ }^{6}$ baik kekuasaan

$\therefore$ Istilah hermeneutika baru muncul pada abad ke tujuh belas, - jauh sebelumnya sudah merupakan wacana baku dalam Islam dengan istilah ilmu tafsir,- diberi pengertian oleh Carl Braaten yaitu sebagai "ilmu yang mencoba menggambarkan bagaimana sebuah kata atau suatu kejadian dalam waktu dan budaya lampau dapàt dimengerti dan menjadi bermakna secara eksistensijal dalam situasi kita sekarang". Sementara itu menunut Rudolf Bultmann: ", istilah hermeneutika secara umum dipakai untuk mendeskripsikan upaya menjembatani jurang antara masa lalu dan masa kini". Farid Isack. 2000: Membebaskan Yang Tertindas. Bandung: Mizan. HIm. 83.

6 Seperti dinyatakan Mulyana W Kusuma, bahwa pembentukan dan realitas kerja hukum sangat dipengaruhi oleh sifat dan karakter negara, dan terikaterat pada hubungan-hubungan kekuasaan politik serta proses perubahan tatanan sosial. Mulyana W Kusuma: 2001. Tegaknya Supremasi Hukum. Bandung: Remaja Rosdakarya. $\mathrm{HIm}$.11. Berdasarkan fakta di Era Orde Baru, pandangan hakim tidak mencerminkan nilai-nilai hukum.yang asasi,- seperti keberpihakan kepada kepentingan publik — dapat dilacak lebih jauh pada.kasus-kasus yang menghadapkan kepentingan rakyat dengan penguasa, seperti sejumlah gugatan PDIP terhadap pemerintah 
domestik maupun asing yang terlibat pada konflik kepentingan dalam suatu perkara. Dari perspektif moral sebagai salah satu elemen penting dalam hukum, hakim berkewajiban dan sekaligus berwenang untuk menentukan suatu putusan yang secara tegas memiliki karakter adil dan benar. Jadi, hakim dengan produk putusannya tetap terikat kepada sikap keberpihakan pada nilai substansial ini. Dalam persepktif ini, akan mudah diaudit, apakah secara metodologis putusan hakim memuat kandungan moral (adil dan benar) sebagai unsur yang asasi atau, mungkin justru mencerminkan keberpihakannya pada pihak yang memiliki pengaruh kuat seperti hainya kasus Kedongombo itu.

Sebaliknya, pada perspektif normatif yang. bersifat positivistik, akan berimplikasi pada terbentuknya paradigma pemikiran hukum yang sangat mengandalkan pada empirisitas atau pengalaman yang jika hal ini tidak dikritik secara mendasar, akan cenderung pada tidak terbukanya tradisi baru bagi pemikiran hukum kritis. ${ }^{7}$ Akibatnya secara sangat pragmatis, akan memunculkan kecenderungan bagi melemahnya dinamika pemikiran hukum yang kritis - dekonstruktif terhadap sejumlah peraturan perundangan maupun doktrin hukum yang sudah lapuk, bahkan secara substansial bertentangan dengan nilai-nilai substansial dari hukum itu sendiri.

\section{Telaah Perspektif Sosiologis}

Dengan telaah ini dimaksudkan untuk menekankan arti penting bagaimana hakim bersama dengan para lawyer sebagai kuasa hukum (adviser) klien, dapat secara sinergis

dimana terdapat keseragaman dalam bentuk gugatan ditolak, petani gurem di Cimacan yang dikalahkan, kasuskasus politik (subversif) seperti Komando Jihad yang kental sekali kesan rekayasa politik aparat intelejen yang dengan rapih merekayasa kalangan umat Islam, dengan lakon ini. Tujuannya untuk memberi kesan bahwa umat Islam sebagai potensi subversif untuk dihadapkan kepada arogansi pemerintah dan tentara yang tanpa reserve berada dibelakang kehendak penguasa Orde Baru. Dalam kasus sejenis ini, tidak satupun pembelaan para pengacara yang diterima oleh hakim. Semua vonis hakim tidak ada yang ringan, sementara mereka yang telah dieksekusi, tidak melalui prosedure yang transparan. Catatan ini merupakan refleksi pengalaman penulis selaku lawyer pada kantor LKBH FH UII dalam mendampingi terdakwa kasus "Sinteron Komando Jihad."

"Pandangan hukum yang dibangun diatas doktrin atau postulat-postulat yang dianggap sudah mapan disuatu tempat tetapi ternyata tidak kontributif bagi penciptaan ruang baru bagi munculnya pemikiran kritis ini, agaknya merupakan suatu keniscayaan, yang dalam tradisi pemikiran Islam dikenal dengan ijtihad sebagai metoda bagaimana suatu pemahaman kritis, rasional dengan tidak tercerahut dari spirit al-Qur'an dan as-Sunah, baik terhadap nash maupun penomena sosiologis dapat ditemukan tafsir baru yang tujuan dasarnya adalah mashlahat (kepentingan publik). Dalam konteks ini dapat dibandingkan dengan munculnya sebuah Gerakan Studi Hukum Kritis di Barat yang dilatarbelakangi oleh kesadaran bahwa doktrin hukum'liberal yang dianut selama ini dinilai tidak memiliki andil bagi pemecahan persolan diskrimanasi ras dan gender, ketidakadilan, kemiskinan, penindasan dan seterusnya. Dalam paradigma GSHK ini ada meanstream bahwa tidak mungkin proses-proses hukum (undang-undang atau penafsiran) berlangsung dalam konteks bebas atau netral dari pengaruh-pengaruh moral, agama dan pluralisme politik (Kata Pengantar Ifdhal Kashim dalam Roberto Unger. 1999. Gerakan Studi Hukum Kritis. Jakarta: ELSHAM.1999. HIm. xv-xii. 
berada dalam satu persepsi, satu kerangka pandang dan satu sikap yuridis di dalam proses persidangan. Dimulai dengan penemuan faktayang dilanjutkan dengan penafsiran atas fakta itu melalui pilihan kritis terhadap sumber peraturan:perundangan, kontrak (kalau ada) dari para pihak yanig bersengketa, yurisprudensi; hukum kebiasaan, dan doktrin hukum, bahkan -bilamana perlu - doktrin di luar hukum, yang kesemuanya itu bermuara pada putusan hakim yang adil dan benar.

Telaah dari aspek sosiologis memiliki relevansi dan faedah bagi penafsiran atas fakta dari peristiwa yang secara konkrit disengketakan para pihak. Suatu sengketa pada umumnya dilatarbelakangi oleh pelanggaran suatu hak baik disebabkan karena perbuatan wan prestasi maupun perbuatan melanggar hukum dlam arti luas. Seperti apa bentuk dan kualitas suatu hak yang dilanggar, demikian juga bentuk pelanggarannya, aspek-aspek hukum apa yang dilanggar, serta sejauh mana kerugian yang diderita oleh pihak yang haknya dilanggar, kesemuanya ini memerlukan suatu telaah yang komprehensif.

Ditinjau dari perspektif ilmu, bangunan ilmu baik yang bersifat teoretik maupun empiris, keduanya bersifat inter-komplementer. Bagaimana suatu praktik ilmu dapat memperoleh pembobotan kualitas teoretiknya sehingga dapat menghasilkan peningkatan validitas ilmiahnya, sedang pada sisi lain melalui penerapan suatu ilmu dalam praktik (empiris) dapat ditemukan unsur-unsur baru yang berguna bagi proses kritik terhadap teori ilmu. Dalam wacana agama, bagaimana terjadi suatu proses simbiotik mutualistik ketika suatu ilmu (teoretik) diterapkan dalam bentuk aksi (empiris) yang kemudian disebut dengan. ilmu amaliah, dibarengi dengan aktivitas yang beršifat praksis (empiris) berdasarkan kaedah ilmiah yang selanjutnya disebut dengan amal ilmiah. Dengan melalui dua pendekatan yang integral ini, empirisitas sosiologis dari bekerjanya ilmu di dalam masyarakat, dapat berfungsi bagi munculnya kritik terhadap validitas suatu ilmu menurut doktrin tertentu maupun terhadap undang-undang.

Ignas Kleden memberikan suatu mekanisme bekerjanya teori dan praktik, dimana teori berikhtiar menyiapkan pengetahuan yang terjamin objektivitasnya, yang kemudian dimanfaatkan dalam praktik. Suatu praktik juga memberikan sesuatu kepada teori, bahwa ada yang bisa dipelajari oleh para teoretisi dari praktik, dan bahwa praktik merupakan hal penting bagi penciptaan teori. Dengan demikian, objektivitas juga tidak berarti menghindar sejuh mungkin dari kondisi-kondisi praktis. Di dalam praktik terkandung dua unsur, salah satunya adalah kepentingan, yang mungkin hendak dilegitimasi oleh pengetahuan yang dibangunnya, yang kemudian menimbulkan masalah, apakah ilmu (khususnya ilmu-ilmu sosial) mengandung ideologi tertentu atau tidak. ${ }^{8}$

Dari perspektif etika profesi yang menuntut cara bekerjanya seorang profesional yaitu selalau mendasarkan pada kaedah ilmu, maka dalam konteks tugas hakim maupun para lawyer, mekanisme seperti Kleden kemukakan

8Ignas Kleden. 1987. Sikap Ilmiah dan Kritik Kebudayaan. Yogyakarta: LP3ES. HIm. 25. 
diatas, menuntut tanggung jawab secara yuridis ilmiah. Dalam bentuk kesungguhan dan kecermatan yang tinggi dalam memahami, memilah dan menafsirkan sejumlah fakta hukum, sebelum melangkah untuk membuat suatu putusan.

Langkah ini cukup rumit, namun bagaimanapun harus ditempuhnya. ${ }^{9}$ Apalagi jika ditinjau dari kedudukan hakim sebagai unsur terpenting badan peradilan, sedang yang disebut terakhir ini merupakan perwujudan dari kekuasaan kehakiman. Maka jika tugas kekuasaan kehakiman adalah menjelmakan Hukum Dasar yang ada di dalam Rechtsidee menjadi kaidah kasus dari hukum positif dalam perkara konkrit, ${ }^{10}$ dapat ditarik pengertian bahwa, 'termasuk tugas hakim adalah terletak pada kemampuan yuridis akademisnya di dalam menemukan asas-asas hukum dari Rechsidee untuk diwujudkan dalam putusan hakim yang bersifat. individual dan konkrit serta mampu menyelesaikan konflik secara tuntas.

$\mathrm{Di}$ atas dikemukan pendapat Kleden mengenai adanya unsur kepentingan di dalam praktik ilmu pengetahuan yang kemudian melahirkan suatu masalah apakah ilmu pengetahuan mengandung unsur ideologi tertentu atau tidak. Mengenai masalah ini, dapat ditinjau dari fungsi ilmu pengetahuan yang, antara lain adalah memprediksi suatu masa depan, untuk mana suatu ilmu pengetahuan dapat diorientasikan bagi pencapaian perwujudan suat masa depan."

Sebagaimana dikemukakan HM Koesnoe, tugas hakim untuk merealisasikan Rechtsidee menjadi putusan yang bersifat individual dan konkrit, mengandung suatu makna bahwa, pendekatan sosiologis yang dilakukan hakim dalam melakukan tafsir atas fakta hukum perlu mempertimbangkan dua unsur. Pertama, unsur kaedah hukum yang relefan dengan fakta hukum. Kedua, unsur pertimbangan yang terkait dengan pendekatan futurologis. Yang kedua ini berkaitan dengan upaya pemikiran akademis untuk menentukan suatu formula yuridis, yaitu apakah suatu putusan hakim, dapat dipertanggungjawabkan secara yuridis akademis jika, putusañ itu bersifat melegitimasi asas-asas yang berlaku dalam hukum acara perdata, yang sekiranya diterapkan, akan menghasilkan suatu putusan yang isinya tidak menganding makna kontribusi yuridis bagi perwujudan Rechtsidee. Misalnya tentang penerapan asas kebenaran formil yang diuraikan diatas.

Jelas sekali bagaimana putusan kasus Kedongombo dalam tingkat peninjauan kembali yang telah menganulir putusan tingkat kasasi yang bersifat egaliter itu, menggambarkan secara gamblang pémikiran hukum yang legal positivistik dan rijid serta membuat putusan demikian teralienasi dan tercerabut dari realitas sosiologis maupun dari

${ }^{9}$ Catatan. Tentang hal ini,dapat Scedikno Mertokusumo bahwa obyek dari ilmu pengetahuan hukum acara perdata ialah keseluruhan peraturan yang bertujuan melaksanakan dan mempertahankan ätau menegakkan hukum perdata materiil dengan perantaran kekuasaan negara. Sudikno Mertokusumo. 1985: Hukum Acara Perdata Indonesia. Yogyakarta: Liberty. HIm. 5.

${ }^{10}$ Lihat selanjutnya dalam HM. Koesnoe. 1998.Kedudukan dan Tugas Hakim Menurut Undangundang Dasar 1945. Surabaya: Ubhara Press. HIm. 48.

"Lihat Yusuf Al Qaradhawi. 1999. Fikih Taysir. Surabaya: Pustaka Kautsar. HIm. 242) 
spirit dan ethical sensibility of justice. Dari perspektif sosiologis, putusan hakim dengan watak pemikiran hukum yang tidak egaliter ini dapat diberi makna yaitu terdapat intellectual and spiritual gap antara pola pikir hukum hakim yang berada pada posisi memenangkan penguasa yang ketika itu masih sangat dominan dalam mengkooptasi semua lini termasuk badan peradilan, dengan komitmennya yang seharus lebih berpihak pada kepentingan perlindungan hukum publik. Menarik untuk dikemukakan contoh lain mengenai tidak adanya sense of crisis suatu putusan hakim, yaitu mengenai putusan majelis hakim yang menjatuhkan hukuman satu tahun penjara bagi terdakwa seorang hakim yang sewaktu masih menjabat Kepala Subdirektorat Kasasi Perdata Mahkamah Agung Republik Indonesia dinyatakan hakim telah menerima uang suap sebesar Rp 550 juta. ${ }^{12}$ Putusan hukuman penjara yang hanya satu tahun ini,- tuntutan jaksa empat tahun —, jika ditelaah dari perspektif sosiologis tidak menunjukkan kepekaan dan concern hakim terhadap gerakan pemberantasan korupsi.

Kualitas putusan hakim yang tidak beremphati pada persoalan besar di masyarakat seperti dicontohkan diatas, disamping menggambarkan cukup dangkalnya penafsiran sosial yaitu tafsir yang didasarkan pada penahaman yang memadai atas realitas empiris masyarakat untuk kemudian dijadikan faktor sosiologis sebagai pertimbangan pengambilan putusan hakim, juga menggambarkan rapuhnya bangunan kosnep filosofis tentang makna keadilan dikalangan hakim. Logikanya, jika korupsi, termasuk tindakan suap kepada pejabat publik, merupakan penomena yang telah berperan bagi hancurnya kekuatan ekonomi bangsa, maka penentuan hukuman yang berat bagi pelaku adalah merupakan bentuk keadilan. Yang menentukan hukuman berat bagi koruptor adalah hakim. Maka logis, jika pelaku tindak pidana korupsi adalah hakim itu sendiri, dijadikan alasan untuk memperberat hukumannya. Tujuan sosiologisnya adalah untuk memberikan pendidikan hukum kepada publik, terutama hakim untuk konsisten dalam menjaga kedudukannya sebagai penegak hukum. Ditinjau dari perspektif pembentukan masyarakat tamaddun diatas, putusan demikian tidak bersifat memperkuat bagi proses pembentukannya, melainkan sebaliknya justru tidak memberi perlindungan atas hak-hak publik yang ikut memiliki kekayaan negara yang hakekatnya milik rakyat bersama.

\section{Telaah Perspektif Yuridis}

Hakim sebagai pembentuk hukum (judge made law), selain mengemban oleh amanat Pembukaan UUD 1945 yang merupakan rechtsidee, Pasal 1, Pasal 4 (ayat 1), Pasal 5 (ayat 1), Pasal 23 (ayat 1) dan Pasal 27 (ayat 1) UU No. 14 Tahun 1970, juga memiliki kedudukan dan peran yang begitu terhormat dan strategis. Terhormat karena pada dirinya dilimpahkan amanat (kepercayaan) masyarakat melalui kekuasaan negara untuk menjadi benteng terakhir bagi penegakan

12Dikemukakan oleh $\mathrm{H}$ Todung Mulya Lubis dalam makalah dengan judul "Peradilan Bebas dan Mandiri?"pada ulang tahun Indonesian Court Monitoring. di Yogyakarta. 30 April 2002. 
keadilan dan kebenaran ketika hukum dilanggar. Dalam praktik, pelanggaran hukum tidak hanya dilakukan oleh sebagian warga negara, melainkan juga berkali-kali dilakukan oleh negara yang seringkali muncul dalam bentuk abuse of power, atau bahkan violence by state. Proses pengadilan untuk jenis pelanggaran hukum yang dilakukan oleh negara sering menghadapi tembok kekuasaan yang pongah dan arogan, sehingga penegakan hukum (law enforcement) mengalami hambatan yang cukup berarti.

Peran strategis hakim terutama terletak pada fungsinya untuk menyelesaikan suatu sengketa ${ }^{13}$ (termasuk pada bidang hukum perdata). Melalui putusan hakim, suatu sengketa yang menimbulkan disequalitas di masyarakat, dapat dipulihkan kembali. Karenanya putusan hakim berfungsi sebagai penyeimbang (restitutio in integrum). Suatu konflik perdata yang semula bersifat individual, jika tidak dikelola dengan memperhatikan kepentingan dan hak-hak publik, dapat berkembang menjadi konflik yang areanya meluas dan kompleks. Dan jika kemudian melibatkan sejumlah besar warga negara berhadapan dengan -kekuasaan, akan berubah menjadi kasus struktural. Oleh karena itu, putusan hakim berfungsi juga bagi pencegahan agar suatu konflik antar individu tidak berkembang menjadi konflik struktural

Untuk menghasilkan putusan hakim yang demikian, hakim telah memperoleh dasar pijakan hukum sebagaimana sejumlah pasalpasal yang dikutip diatas. Dengan terdapatnya asas kebebasan hakim, ia leluasa untuk mengkonstruksi bagaimana suatu putusan dapat berfungsi sebagai penyelesai konflik. Artinya secara profesional ia memiliki legalitas untuk melakukan penilaian yang bersifat kritis termasuk terhadap sejumlah asas-asas hukum acara perdata yang sekiranya sudah tidak relefan lagi. Apalagi dengan sifat yang melekat pada suatu asas yaitu elastis dan dinamis terhadap perubahan tatanilai yang terjadi di dalam masyarakat.

Karena suatu asas secara umum bersifat elastis dan dinamis itulah, maka asas yang cukup fundamental di dalam Pasal 1 UU No. 14 Tahun 1970 yaitu kebebasan hakim, menjadi relefan untuk diartikan dengan pengertian bahwa hakim memiliki kewenangan luas untuk secara etis-profesional memadukan asas kebebasan hakim, dengan asas akuntabililitas vertikal terhadap Allah SWT dan terhadap publik (Pasal 4 ayat (1) jo Pasal 23), asas objektivitas (Pasal 5 ayat (1)), asas keterbukaan umum (Pasal 17 jo Pasal 18) UU №. 14 Tahun 1970.

Pemaduan sejumlah asas ini masih perlu disertai dengan sikap kritis secara yuridis akademis di dalam memahami sejumlah aturan perundangan dan doktrin-doktrin hukum acara perdata yang terlanjur disikapi secara rijid (kaku). Cukup alasan kiranya bagi hakim untuk secara bebas memberlakukan atau tidak memberlakukan aturan perundangan ataupun doktrin tertentu, dengan parameter yang jelas dan argumentasi logika hukum yang benar serta akuntabel. Sejalan dengan spirit keadilan dalam perspektif Ketuhanan Yang Maha Eșa (Pasal 4 ayat (1)

${ }^{13}$ Lihat N.E. Algra dan Van Duyvendijk.1983. Mula Hukum. Bandung: Binacipta.Hilm. 382. 
UU No. 14 Tahun 1970), maka semangat untuk berfikir keras bagi penemuan hukum atau ijtihad dalam arti lebih substansial membuka ruang dan peluang bagi muńculnya pemikiran yang bersifat kritis dekonstruktif sekalipun, sebagaimana putusan Khalifah "Umar ibn Khatab dan Hakim Agung Asikin Kusuma Atmaja yang dituturkan di atas.

Dengan demikian terhadap kecenderungan hakim yang memandang suatu asas hukum dalam arti umum maupun yang secara spesifik asas hukum acara perdata sebagai postulat yang bersifat final, tidak relefan lagi bagi pengembangan dan penguatan kualitas maupun fungsi-fungsi yuridis sosiologis dari putusan hakim. Apalagi berkaitan dengan proses-proses pembentukan masyarakat tamaddun yang digambarkan sebagai masyarakat yang berkeadilan, transparan dan demokratis dengan pengakuan dan penghormatan àtas hak-hak dan kewajiban-kewajiban asasi manusia, dimana sikap kritis para hakim memeliki peran signifikan.

\section{Simpulan}

Pemikiran kritis terhadap asas-asas hukum acara perdata, perlu diletakkan dalam bingkai dan spektrum pemikiran yang komprehensif yaitu bagaimana peran-peran badan peradilan, terutamà melalui independensi-dan profesionalitas hakim dapat lebih menempatkan badan yudikatif ini dalam agenda-agenda yang lebih mendasar yaitu, memberi kontribusi: bagi penyelesaian konflik keperdataan, memulihkan dan mendistribusi hak dan kewajiban secara proporsional, memulihkan keseimbangan publik, memberikan perlindungan hukum bagi perorangan dengan mempertimbangkan hakhak dan kepentingan publik dan last but not least membangun tradisi baru bahwa badan peradilan dalam sistem ketatanegaraan dan agenda pembangunan Masyarakat Tamaddun, berada dalam posisi independen dan kritis dengan menutup rapat celah-celah masuknya intervensi penguasa dan tentu saja intervensi yang datang dari diri dan keluarga maupun kolega Sang Penegak Keadilan dan Kebenaran ini.

\section{Daftar Pustaka}

Algra, N.E. dan Van Duyvendijk.1983. Mula Hukum. Bandung: Binacipta.

Basyir, Ahmad Azhar . 1993. MA: Refleksi atas Persoalan Keislaman. Bandung: Mizan.

Fakih, Mansour. 1996. Masyarakat Sipil. Yogyakarta: Pustaka Pelajar.

Khadduri, Majid. 1999. Teologi Keadilan; Perspektif Islam. Risalah Gusti.

Kleden, Ignas. 1987. Sikap IImiah dan Kritik Kebudayaan. Yogyakarta: LP3ES.

Koesnoe, HM. 1998.Kedudukan dan Tugas Hakim Menurut Undang-undang Dasar 1945. Surabaya: Ubhara Press.

Kusuma, Mulyana W. 2001. Tegaknya Supremasi Hukum. Bandung: Remaja Rosdakarya.

Lev, Daniel S.. 2001. Advokat Indonesia Mencari Legitimasi. Jakarta, PSHK dan The Asia Foundation.

Lubis, Todung Mulya dalam makalah dengan judul "Peradilan Bebas dan Mandiri?"pada ulang tahun Indonesian 
Court Monitoring. di Yogyakarta. 30 Unger, Roberto. 1999. Gerakan Studi Hukum April 2002. Kritis. Jakarta: ELSHAM.1999.

Mertokusumo, Sudikno. 1985. Hukum Acara Kompas. 17 Oktober. 1994.

Perdata Indonesia. Yogyakarta: Liberty.

Qaradhawi, Yusuf Al. 1999. Fikih Taysir.

Surabaya: Pustaka Kautsar.

60

Muh Busyro Muqoddas. Staf Pengajar FH UII dan Kepala Divisi Kerjasama Pus Ham Ull. 